\title{
Higher polygenic risk scores for schizophrenia may be suggestive of treatment non-response in major depressive disorder
}

Giuseppe Fanelli ${ }^{1}$, Francesco Benedetti ${ }^{2}$, Siegfried Kasper ${ }^{3}$, Alexander Kautzky ${ }^{3}$, Joseph Zohar ${ }^{4}$, Daniel Souery ${ }^{5}$, Stuart Montgomery ${ }^{6}$, Diego Albani ${ }^{7}$, Panagiotis Ferentinos ${ }^{8}$, Dan Rujescu ${ }^{9}$, Julien Mendlewicz $^{10}$, Alessandro Serretti ${ }^{1 *}$, Chiara Fabbri ${ }^{11}$

${ }^{1}$ Department of Biomedical and Neuromotor Sciences, University of Bologna, Italy

${ }^{2}$ Psychiatry and Clinical Psychobiology Unit, Division of Neuroscience, San Raffaele Scientific Institute, Milan, Italy

${ }^{3}$ Department of Psychiatry and Psychotherapy, Medical University Vienna, Austria

${ }^{4}$ Department of Psychiatry, Sheba Medical Center, Tel Hashomer, and Sackler School of Medicine, Tel Aviv University, Israel

${ }^{5}$ Laboratoire de Psychologie Médicale, Université Libre de Bruxelles and Psy Pluriel, Centre Européen de Psychologie Médicale, Brussels

${ }^{6}$ Imperial College School of Medicine, London, UK

${ }^{7}$ Laboratory of Biology of Neurodegenerative Disorders, Neuroscience Department, Istituto di Ricerche Farmacologiche Mario Negri IRCCS, Milan, Italy

${ }^{8}$ Department of Psychiatry, Athens University Medical School, Athens, Greece

${ }^{9}$ University Clinic for Psychiatry, Psychotherapy and Psychosomatic, Martin-Luther-University Halle-Wittenberg, Germany

${ }^{10}$ Université Libre de Bruxelles

11 Social, Genetic \& Developmental Psychiatry Centre, Institute of Psychiatry, Psychology \& Neuroscience, King's College London, UK

* Corresponding author:

Alessandro Serretti, MD, PhD

Department of Biomedical and Neuromotor Sciences,

University of Bologna,

Viale Carlo Pepoli 5, 40123 Bologna, Italy

Tel +390516584233

Fax +39051521030

Mobile +393204269332+393473024020

Email: alessandro.serretti@unibo.it 


\begin{abstract}
Background. Up to $60 \%$ of patients with major depressive disorder (MDD) do not respond to the first treatment with antidepressants. Response to antidepressants is a polygenic trait, although its underpinning genetics has not been fully clarified. This study aimed to investigate if Polygenic Risk Scores (PRSs) for major psychiatric disorders and neuroticism were associated with non-response or resistance to antidepressants in MDD.

Methods. PRSs for bipolar disorder, MDD, neuroticism, and schizophrenia (SCZ) were computed in 1148 MDD patients recruited by the European Group for the Study of Resistant Depression. Summary statistics from largest meta-analyses of genome-wide association studies were used as base data. Patients were classified as responders, non-responders to one treatment, non-responders to two or more treatments (treatment-resistant depression or TRD). Regression analyses were adjusted for population stratification and recruitment sites.
\end{abstract}

Results. PRSs did not predict either non-response or TRD after Bonferroni correction. However, SCZ-PRS was nominally associated with non-response $(\mathrm{p}=0.003)$. Patients in the highest SCZ-PRS quintile were more likely to be non-responders than those in the lowest quintile (OR=2.23, 95\% $\mathrm{CI}=1.21-4.10, \mathrm{p}=0.02)$. Patients in the lowest SCZ-PRS quintile showed higher response rates when they did not receive augmentation with second-generation antipsychotics (SGAs), while those in the highest SCZ-PRS quintile had a poor response independently from the treatment strategy $(\mathrm{p}=0.009)$.

Conclusions. A higher genetic liability to SCZ may reduce responsiveness to pharmacological treatment in MDD. From a clinical point of view, our results suggest that MDD patients with low SCZ-PRS do not benefit from augmentation with SGAs.

Keywords: Treatment-resistant depression; Depression; Antidepressants; Polygenic Risk Scores; GWAS; Personalized medicine; Pharmacogenomics 


\section{Introduction}

Major depressive disorder (MDD) is a leading cause of disability worldwide, and it constitutes a serious economic burden for society (Greenberg et al., 2015, WHO, 2017). Up to 60\% of adequately treated patients with MDD do not reach a complete response to the first antidepressant, and about one-third shows resistance, failing to respond to multiple treatments (De Carlo et al., 2016). Treatment-resistant depression (TRD) was reported to six-fold increase health care costs, especially due to a higher frequency of hospitalizations and accesses to psychiatric outpatient services (Crown et al., 2002). In addition to its impact on health care costs, TRD is associated with a higher risk of suicide, and a greater recurrence of depressive episodes over time (Mrazek et al., 2014). These burdensome consequences have led to a major effort to identify clinical and biological predictors of non-response and TRD, which might guide clinical decisions. In this regard, multivariate models were developed to predict treatment response using machine learning approaches. Promising results were obtained by using clinical-demographic predictors or their combination with genetic variants or multi-marker genetic scores (Kautzky et al., 2015, Kautzky et al., 2018, Niculescu et al., 2015), despite replication in independent samples remains the main issues of predictive modelling in this research field.

The lack of consistent replication of findings is related to the complex genetic architecture of treatment response, whose biological underpinnings have not been completely elucidated. Response to antidepressants has a relevant genetic basis ( $42 \%$ of its variance is attributed to common genetic variants) and it is highly polygenic (Tansey et al., 2013). This is one of the main reasons why candidate gene studies and genome-wide association studies (GWAS) provided mostly nonreplicated or non-significant findings (Fabbri et al., 2019, Niitsu et al., 2013, Wigmore et al., 2019). The use of aggregated polygenic approaches provided more interesting results, hence the higher power of these methods (Fabbri et al., 2019). Polygenic Risk Scores (PRSs) take into account the effect of multiple SNPs across the genome and they capture the polygenic nature of treatment response, which is characterized by the conjunct effect of a number of loci, each with a small effect not reaching the genome-wide significance threshold in relatively small samples (Wray et al., 2007, 2008). PRSs have been effectively applied in other branches of medicine to identify patients having increased risk for multifactorial diseases. For example, PRSs were able to identify individuals having more than three-fold risk of developing breast cancer, inflammatory bowel diseases, type-2 diabetes, and cardiac diseases, increasing up to 20 -fold the proportion of subjects at risk who can be identified compared to screening for rare monogenic variations (Khera et al., 2018). Disclosing clinical risk indices estimated using PRSs for Coronary Artery Disease to patients also led to better 
control of cholesterol levels through facilitated acceptance of statin therapies (Kullo et al., 2016). PRSs will likely become a valuable tool to stratify patients with different risk or prognosis. As genotyping costs decrease, it will be increasingly possible to include polygenic information into electronic health records, facilitating the integration with clinical data.

PRSs have also been used to test the genetic overlap between potentially related traits (GarciaGonzalez et al., 2017, Tansey et al., 2014, Ward et al., 2018). A shared genetic aetiology has been highlighted for bipolar disorder (BD), MDD, and schizophrenia (SCZ), with their risk variants showing a moderate genetic correlation (Schizophrenia Working Group of the Psychiatric Genomics, 2014, Stahl et al., 2019), and genetic variants conferring risk for those disorders might also have an effect on treatment response. Neuroticism (NEU) has shown moderate to high positive genetic correlation with resistance to antidepressants and depression, respectively [18, 19]. So far, PRSs for BD, MDD, and SCZ have not been associated with response to antidepressants in MDD (Garcia-Gonzalez et al., 2017, Tansey et al., 2014, Ward et al., 2018), while SCZ-PRS was associated with poorer antipsychotic and lithium response in SCZ and BD, respectively (International Consortium on Lithium et al., 2018, Zhang et al., 2019). NEU-PRSs were shown to have a negative effect on response to antidepressants (Amare et al., 2018, Ward et al., 2018), as well as to significantly predict MDD case-control status, explaining $1.05 \%$ of the phenotypic variance (Genetics of Personality et al., 2015).

This study aimed to investigate if PRSs for BD, MDD, NEU and SCZ are associated with nonresponse or resistance to antidepressants in patients with MDD, based on the hypothesis that the genetic susceptibility to these traits may represent a stratification factor in treatment response. Associations with these PRSs may help in stratifying MDD patients according to their risk of treatment-resistance and provide useful clinical information.

\section{Methods}

\subsection{Target sample: European Group for the Study of Resistant Depression (GSRD)}

\subsubsection{Sample participants}

The sample included 1346 adults recruited by the European Group for the Study of Resistant Depression (GSRD) within a multicentre study. All the participants were diagnosed with MDD according to DSM-IV-TR criteria by the Mini International Neuropsychiatric Interview (MINI) (APA, 2000, Sheehan et al., 1998). Inclusion criteria included treatment with at least one antidepressants at an adequate dose for $\geq 4$ weeks during the current MDD episode and a Montgomery-Åsberg Depression Rating Scale (MADRS) score >22 at the beginning of the current episode (Montgomery and Åsberg, 1979). Patients were excluded if they were diagnosed with any 
other primary psychiatric disorder or substance disorder in the preceding six months. MADRS was used to measure the current depressive symptom severity and that at the onset of the current MDD episode. Careful pharmacological anamnesis related to the present MDD episode, as well as clinical and socio-demographic data, were collected. Treatment with antidepressants was conducted naturalistically following best clinical practice principles.

All procedures involved in this study conform to the ethical standards of the Helsinki Declaration. All procedures were approved by the local ethics committees of each recruiting centre (coordinating centre approval number: B406201213479). Additional details can be found elsewhere (Dold et al., 2018). All patients included in this study provided written informed consent.

\subsubsection{Phenotypes}

Patients were classified in responders, non-responders, and TRD. Response was defined as a MADRS score <22 and a decrease of at least $50 \%$ compared to the onset of the current MDD episode after at least four weeks of treatment. Non-responders were patients who did not respond to one antidepressant during the current episode. TRD was defined as a lack of response to at least two antidepressants of adequate duration (at least four weeks) and dose.

\subsubsection{Genotyping and quality control $(Q C)$}

All individuals were genotyped using the Illumina Infinium PsychArray 24 BeadChip (Illumina, Inc., San Diego) platform.

Pre-imputation QC was performed by removing SNPs with a genotype missing rate $\geq 5 \%$ and monomorphic variants. Participants were excluded if they had a genotyping rate $<97 \%$, sex discrepancies, abnormal heterozygosity, high relatedness (identity by descent (IBD) >0.1875) (Anderson et al., 2012), or if they were not of Caucasian ethnicity. Population outliers were defined as those outside five standard deviations for the first 20 population principal components obtained on linkage-disequilibrium (LD)-pruned genetic data (Patterson et al., 2006).

Genotype imputation was conducted using the Haplotype Reference Consortium (HRC) r1.1 2016 data as reference panel and Minimac3. After imputation, variants with poor imputation quality $\left(r^{2}\right.$ (estimated squared correlation between imputed genotypes and true genotypes) <0.30) (Li et al., 2010), minor allele frequency $(\mathrm{MAF})<0.01$ and genotype probability $<0.90$ were pruned.

\subsection{Polygenic risk scores (PRSs)}

PRSs for BD, MDD, NEU and SCZ were calculated as the sum of risk alleles at trait-associated loci, weighted for the effect-sizes derived from the largest and most recent genome-wide meta- 
analyses of the Psychiatric Genomics Consortium (PGC-II studies) on BD, MDD and SCZ, and from the study by Baselmans et al. for NEU (Baselmans et al., 2019a, Howard et al., 2018, Schizophrenia Working Group of the Psychiatric Genomics, 2014, Stahl et al., 2019, Wray et al., 2018). Further information on base samples is reported in Table 1.

PRSs calculation in the target sample was performed using PRSice-2 software (Choi and O'Reilly, 2019). For genome-wide PRSs, clumping was carried out in PRSice- 2 considering a ${ }^{2}$ threshold of 0.1 and a window of $250 \mathrm{~kb}$ to remove SNPs in high linkage disequilibrium (LD) since they would have inflate PRSs (Wray et al., 2018). The base summary statistics were filtered according to an INFO score of 0.4. For each subject, we computed different genome-wide PRSs based on a priori set of eight P-value thresholds $\left(\mathrm{P}_{\mathrm{T}}\right)$ (i.e., 1e-4, 0.001, 0.05, 0.1, 0.2, 0.3, 0.4, 0.5), to identify the best threshold for predicting the outcomes of interest. Empirical p-values $\left(\mathrm{p}_{\mathrm{E}}\right)$ were calculated by performing 10k permutations in order to avoid overfitting and Type-I error (Choi and O'Reilly, 2019). Additional Bonferroni correction was applied to account for the four base psychiatric traits and two binary phenotypes tested (alpha $=0.05 / 8=0.006$ ). The most predicting genome-wide PRSs were decomposed by using a gene-set PRS approach to pinpoint the biological pathways that contributed most to the association. Gene-set PRSs were calculated by using the PRSet function in PRSice-2. A list of gene-sets, previously associated with base and target traits was derived from the most recent PGC genome-wide studies and GWAS Atlas (Schizophrenia Working Group of the Psychiatric Genomics, 2014, Watanabe et al., 2019, Wray et al., 2018) and downloaded from the Molecular Signatures Database (MSigDB) v7.0. The genes in each pathway were matched to their genome boundaries according to human assembly GRCh37-hg19. Clumping was performed for each gene-set separately using a window of $1 \mathrm{Mb}$. Since flanking SNPs not physically located within the gene-set region might also influence functions of the set, a cut-off (proxy threshold) of r2 $\geq 0.8$ was used for gene-set membership. Pathway-based PRSs were calculated at $\mathrm{P}_{\mathrm{T}}=1$ only, because gene-set PRSs containing a small portion of SNPs may be unrepresentative of the whole gene-set. For each gene-set PRS, a self-contained p-value and a competitive p-value were provided, which respectively tested the association with the target phenotype and the enrichment of signal of the specific gene-set. The competitive p-value was obtained by comparing the observed gene-set PRS association with the 10k permuted null p-value distribution of random gene-sets PRSs. Bonferroni correction, accounting for the multiple tested gene-sets, was applied (alpha=0.05/(23 tested gene-sets) $=0.0022$ ).

PRSs were used as predictors in regression models where two binary treatment outcomes were considered (response vs. non-response, response vs. TRD). Regression analyses were adjusted for population stratification and recruitment sites. The proportion of variance in non-response or 
resistance explained by the PRSs was estimated by Nagelkerke's pseudo- $\mathrm{R}^{2}$ by the difference between the $\mathrm{R}^{2}$ of the full model, containing the PRS and the covariates, and the $\mathrm{R}^{2}$ of the null model, which contains only the covariates.

\subsection{Power analyses}

The statistical power of the PRSs at each $\mathrm{P}_{\mathrm{T}}$ was calculated using the AVENGEME R-package (Dudbridge, 2013, Palla and Dudbridge, 2015). SNP-based heritability $\left(\mathrm{h}^{2}{ }_{\mathrm{SNP}}\right)$ estimated from the used summary statistics was 0.2 for BD, 0.1 for MDD, 0.12 for NEU, and 0.25 for SCZ (Baselmans et al., 2019b, Howard et al., 2018, Schizophrenia Working Group of the Psychiatric Genomics, 2014, Stahl et al., 2019). Genetic covariance between traits in the base and target datasets were hypothesized to be $25 \%$ or $50 \%$, according to a previous study (Garcia-Gonzalez et al., 2017). Assuming a covariance of $50 \%$ between traits, all the analysed PRSs showed adequate power between $90 \%$ and $100 \%$. The power of BD-PRSs decreased to a range of $18 \%-67 \%$ when covariance was set to $25 \%$, while adequate power $(>80 \%)$ was observed for the other PRSs.

\section{Results}

After QC, 1148 patients were included from GSRD. The clinical-demographic characteristics of this sample are shown in Supplementary Table S1. Overall, 7,605,870 variants passed QC procedures.

Regression models were adjusted for the first nine population principal components, along with recruitment centres, since they minimized the genomic inflation factor (Supplementary Fig. S1).

\subsection{Associations between PRSs and response to antidepressants}

PRSs for BD, MDD, NEU and SCZ were not associated either with non-response or resistance to antidepressants after correction for multiple testing. Summary of results for the best $\mathrm{P}_{\mathrm{T}}$ (lowest pvalues) is reported in Table 1.

PRSs for BD showed p-values>0.05 for all the considered $\mathrm{P}_{\mathrm{T}}$ (Supplementary Figs. S2-S3).

PRSs for MDD showed nominal associations with non-response at four $\mathrm{P}_{\mathrm{T}}\left(\mathrm{p}=0.032\right.$ and $\mathrm{p}_{\mathrm{E}}=0.10$ at the best $\mathrm{P}_{\mathrm{T}}$ ), explaining between $0.7 \%$ and $0.9 \%$ of the total variance in the outcome (Supplementary Figs. S4-S5). All the nominally significant associations showed a consistent direction of effect, with higher PRSs associated with a higher probability of non-response.

NEU-PRSs did not predict either non-response or resistance to antidepressants. A weak nominal association with TRD was observed at $\mathrm{P}_{\mathrm{T}}=0.001\left(\mathrm{p}=0.049, \mathrm{p}_{\mathrm{E}}=0.154\right)$ (Supplementary Figs. S6-S7). 
SCZ-PRS was nominally associated with non-response at six $\mathrm{P}_{\mathrm{T}}$, explaining between $1.1 \%$ and $1.6 \%$ of the total variance in the outcome (Fig. 1a). The strongest association was found at $\mathrm{P}_{\mathrm{T}}$ of 0.1 $\left(\mathrm{p}=0.003, \mathrm{p}_{\mathrm{E}}=0.014\right)$. At $\mathrm{P}_{\mathrm{T}}=0.1$, patients in the highest SCZ-PRS quintile were more likely to be non-responders than those in the lowest reference quintile $(\mathrm{OR}=2.23,95 \% \mathrm{CI}=1.21-4.10, \mathrm{p}=0.02)$ (Fig. 1b). No pathway SCZ-PRS was associated with non-response, neither we showed enrichment for any gene-set. Nominal associations were shown for SCZ-PRSs of the gene-sets GO:0050890 (cognition; p=0.007), GO:0044309 (neuron spine; p=0.024), GO:0010975 (regulation of neuron projection development; 0.028), GO:0021953 (central nervous system neuron differentiation; $\mathrm{p}=0.034$ ) and GO:0048667 (cell morphogenesis involved in neuron differentiation; $\mathrm{p}=0.037$ ), explaining between $0.8 \%$ and $1.3 \%$ of the phenotypic variance (Supplementary Fig. S9; Supplementary Table S2).

\subsection{Clinical significance of the association between SCZ-PRS and non-response to antidepressants}

Post-hoc univariate analyses showed that patients in the highest SCZ-PRS quintile were more frequently treated with second-generation antipsychotic (SGA) augmentation compared to patients in the lowest SCZ-PRS quintile ( $\mathrm{p}=0.007$ ). This was not due to a different distribution of psychotic symptoms between the two groups $(\mathrm{p}=0.07)$. The difference seems rather the consequence of a higher severity of depressive symptoms in patients in the highest SCZ-PRS quintile compared to those in the lowest quintile, in terms of current MADRS score and MADRS score at the onset of the depressive episode $(\mathrm{p}=3.5 \mathrm{e}-4$ and $\mathrm{p}=0.003$, respectively). Patients in the upper SCZ-PRS quintile also showed a greater number of previous depressive episodes and a more frequent family history of suicide compared to those in the lowest quintile ( $\mathrm{p}=0.005$ and $\mathrm{p}=0.026$, respectively). Besides, they were more likely to be unemployed and to live alone ( $\mathrm{p}=0.003$ and $\mathrm{p}=0.028$, respectively). Patients receiving augmentation with SGAs did not show higher chances of response compared to patients receiving no augmentation in either group ( $\mathrm{p}=0.665$ and $\mathrm{p}=0.141$, respectively). Patients who did not receive augmentation with SGAs were more likely to be responders in the lowest SCZ-PRS quintile than those in the highest quintile ( $\mathrm{p}=0.009$ ) (Fig. 2), suggesting that patients in the highest quantile do not respond well to any treatment strategy and patients in the lowest quantile respond better to antidepressant monotherapy than antidepressant augmentation with SGAs. Consistently, patients treated with SGA augmentation did not show any difference in response rate depending on the SCZ-PRS quantile they belong to $(\mathrm{p}=0.972)$. Detailed results are reported in Table 2 .

\section{Discussion}


The present study investigated if PRSs for BD, MDD, NEU or SCZ were associated either with non-response or resistance to antidepressants in a sample of 1148 patients with MDD. Although PRSs did not show any significant effect after multiple-testing correction, non-responders to antidepressants showed trends of higher SCZ-PRSs and MDD-PRSs ( $p=0.003$ and $\mathrm{p}=0.032$, respectively). MDD patients showing higher genetic risk for SCZ were more likely to receive augmentation with antipsychotics. This clinical choice seemed driven by higher depression severity (higher MADRS score, higher number of previous episodes, higher functional impairment), rather than higher frequency of psychotic features in this group of patients. However, SGA augmentation did not improve response rates in these patients, who did not respond well to any treatment strategy. On the other hand, patients in the lowest SCZ-PRS quantile showed better response rates when they received antidepressant therapy compared to SGA augmentation, suggesting that they do not benefit or poorly tolerate this treatment. We might speculate that a higher liability to SCZ may lead to a clinically and biologically different subtype of depression, therefore less responsive to pharmacological treatments for depression. In line with this hypothesis, depressive and negative symptoms are poorly responsive to the available pharmacological treatments in SCZ (Buoli et al., 2016) and MDD with high SCZ-PRS was associated with less neuroticism and psychological distress and greater cognitive deficits (Whalley et al., 2016). Shared genetic loci between MDD and SCZ may be a starting point to identify therapeutic targets for new treatments effective in MDD with high SCZ-PRS. These loci include the major histocompatibility complex (MHC) region [27], which is involved in synaptic functionality and plasticity by modulating the activity of glutamatergic receptors and microglia-mediated synaptic pruning [36]. Glutamatergic and immune dysfunctions were linked with non-response to antidepressants, and drugs such as the Tumor Necrosis Factor (TNF)-alpha antagonist infliximab and the N-methyl-D-aspartate (NMDA)receptor antagonist ketamine showed efficacy in MDD cases non-responsive to traditional treatments (Fond et al., 2014, Kim and Na, 2016). Thus, we speculate that MDD patients with higher PRSs for schizophrenia might respond better to drugs that modulate the glutamatergic and/or immune functions, but this hypothesis needs to be tested. Nevertheless, our gene-set approach was not able to demonstrate associations between any tested pathway-specific SCZ-PRSs and nonresponse to antidepressants and neither enrichment for the corresponding pathways. Cumulative genome-wide SCZ-PRSs, although less informative of the underpinning biology, were able to predict non-response better than the tested pathway-specific SCZ-PRSs.

To the best of our knowledge, this was the first study to indicate a suggestive overlap between SCZ genetic risk and non-response to antidepressants. Previously, in a combined target sample of $\sim 3700$ depressed patients, no association between SCZ-PRSs and symptom improvement to 
antidepressants was observed, although SCZ-PRS showed a trend of association $(\mathrm{p}=0.07)$ and better results compared to MDD-PRS (Garcia-Gonzalez et al., 2017). Differently from this previous study, we investigated treatment non-response and resistance rather than considering a quantitative measure of response which is more difficult to interpret in terms of clinical significance. Our findings do not support an effect of MDD-PRS on antidepressants response, although a weak trend of association with non-response was found. Although it has not yet been replicated in adults, MDD-PRSs predicted depressive symptom severity in youths, which is a major risk factor for nonresponse to antidepressants (Halldorsdottir et al., 2019, Kautzky et al., 2019). Depressed patients assigned to electroconvulsive therapy, who often show a more severe and resistant phenotype, showed higher MDD-PRSs as well (Foo et al., 2019). Thus, a higher MDD-PRS may result in treatment non-response by the modulation of symptom severity. It is worth noting that PRSs for MDD were computed based on a GWAS meta-analysis of self-reported depressive symptoms and help-seeking behaviour, as well as clinically diagnosed MDD (Howard et al., 2018, Wray et al., 2018). It was shown that GWAS signals for minimal phenotyping-based depression might have lower specificity for MDD than those based on DSM criteria (Cai et al., 2018).

BD-PRSs did not predict response to antidepressants, in line with previous evidence (Tansey et al., 2014), while NEU-PRS showed a nominal effect on the risk of TRD, consistently with a previous GWAS (Ward et al., 2018), but no effect on the risk of non-response, suggesting that TRD may have a specific genetic profile. As opposed to non-response, we hypothesised that TRD might be modulated by specific genetic factors that do not significantly overlap with major psychiatric disorders, but which could be more related to personality traits.

These findings should be interpreted in light of the limitations of this study. The power of the study was estimated to be adequate for the greatest part of the performed tests, except for BD-PRS, but we did not evaluate the performance of the calculated PRSs in an independent sample or by performing cross-validation because of the size of target sample (Choi et al., 2018). Nevertheless, we used a permutation strategy to avoid overfitting and derive empirical p-values. The use of genesets is limited by current knowledge about the functioning and genes involved in the corresponding pathways. It is worth noting that PRSs consider only common genetic variants in predicting shared genetic risk between different complex traits, without considering the effect of rare variants. Finally, PRSs assume an additive effect and do not take into account any potential interactive or epistatic effect between variants.

In conclusion, this study did not identify any significant association between PRSs for three major psychiatric disorders, neuroticism and response to antidepressants, however it found a nominal association between higher SCZ-PRSs and non-response to antidepressants in MDD, an effect that 
should be confirmed in independent samples. If replicated, this result suggests that MDD with a higher genetic load for SCZ may represent a different biological subtype, which has lower response rates to both antidepressants and antidepressant augmentation with antipsychotics. In line with this hypothesis, patients with high SCZ-PRS showed higher symptom severity, higher disease recurrence, as well as higher evidence of functional impairment in relevant areas of life (work and intimate relationships). Patients with a low SCZ-PRS showed better response rates when treated with antidepressants only and not with SGA augmentation, suggesting that this group does not benefit from SGA augmentation but on the contrary it could cause detrimental side effects and no symptom improvement. 


\section{Conflicts of interest}

S. Kasper received grants/research support, consulting fees and/or honoraria within the last three years from Angelini, AOP Orphan Pharmaceuticals AG, AstraZeneca, Eli Lilly, Janssen, KRKAPharma, Lundbeck, Neuraxpharm, Pfizer, Pierre Fabre, Schwabe, and Servier. D. Souery has received grant/research support from GlaxoSmithKline and Lundbeck, and he has served as a consultant or on advisory boards for AstraZeneca, Bristol-Myers Squibb, Eli Lilly, Janssen, and Lundbeck. S. Mendlewicz is a member of the board of the Lundbeck International Neuroscience Foundation and of the advisory board of Servier. A. Serretti is or has been consultant/speaker for Abbott, Abbvie, Angelini, AstraZeneca, Clinical Data, Boheringer, Bristol-Myers Squibb, Eli Lilly, GlaxoSmithKline, Innovapharma, Italfarmaco, Janssen, Lundbeck, Naurex, Pfizer, Polifarma, Sanofi, and Servier. J. Zohar has received grant/research support from Lundbeck, Servier, and Pfizer; he has served as a consultant on the advisory boards for Servier, Pfizer, Solvay, and Actelion; and he has served on speakers' bureaus for Lundbeck, GSK, Jazz, and Solvay. S. Montgomery has been consultant or served on advisory boards for AstraZeneca, Bionevia, BristolMyers Squibb, Forest, GlaxoSmithKline, Grunenthal, Intellect Pharma, Johnson \& Johnson, Lilly, Lundbeck, Merck, Merz, M's Science, Neurim, Otsuka, Pierre Fabre, Pfizer, Pharmaneuroboost, Richter, Roche, Sanofi, Sepracor, Servier, Shire, Synosis, Takeda, Theracos, Targacept, Transcept, UBC, Xytis, and Wyeth. The other authors declare no conflict of interest.

\section{Acknowledgements}

We are grateful to all the participants who took part in the GSRD study and the PGC for making publicly available the GWAS summary statistics that we used as base data for our PRS analyses.

\section{Financial support}

The Group for the Study of Resistant Depression (GRSD) was supported by an unrestricted grant from Lundbeck that had no further role in the study design, data collection, analysis and interpretation, as well as in writing and submitting of the manuscript for publication. 


\section{References}

Amare, A. T., Schubert, K. O., Tekola-Ayele, F., Hsu, Y. H., Sangkuhl, K., Jenkins, G., Whaley, R. M., Barman, P., Batzler, A., Altman, R. B., Arolt, V., Brockmoller, J., Chen, C. H., Domschke, K., Hall-Flavin, D. K., Hong, C. J., Illi, A., Ji, Y., Kampman, O., Kinoshita, T., Leinonen, E., Liou, Y. J., Mushiroda, T., Nonen, S., Skime, M. K., Wang, L., Kato, M., Liu, Y. L., Praphanphoj, V., Stingl, J. C., Bobo, W. V., Tsai, S. J., Kubo, M., Klein, T. E., Weinshilboum, R. M., Biernacka, J. M. \& Baune, B. T. (2018). Association of the Polygenic Scores for Personality Traits and Response to Selective Serotonin Reuptake Inhibitors in Patients with Major Depressive Disorder. Front Psychiatry 9, 65.

Anderson, G. R., Galfin, T., Xu, W., Aoto, J., Malenka, R. C. \& Sudhof, T. C. (2012). Candidate autism gene screen identifies critical role for cell-adhesion molecule CASPR2 in dendritic arborization and spine development. Proc Natl Acad Sci U S A 109, 18120-5.

APA, A. J. W., DC: American Psychiatric Association, (2000). Diagnostic and statistical manual of mental disorders: DSM-IV-TR.

Baselmans, B. M. L., Jansen, R., Ip, H. F., van Dongen, J., Abdellaoui, A., van de Weijer, M. P., Bao, Y., Smart, M., Kumari, M., Willemsen, G., Hottenga, J. J., consortium, B., Social Science Genetic Association, C., Boomsma, D. I., de Geus, E. J. C., Nivard, M. G. \& Bartels, M. (2019a). Multivariate genome-wide analyses of the well-being spectrum. Nat Genet 51, 445451.

Baselmans, B. M. L., van de Weijer, M. P., Abdellaoui, A., Vink, J. M., Hottenga, J. J., Willemsen, G., Nivard, M. G., de Geus, E. J. C., Boomsma, D. I. \& Bartels, M. (2019b). A Genetic Investigation of the Well-Being Spectrum. Behav Genet 49, 286-297.

Buoli, M., Serati, M., Ciappolino, V. \& Altamura, A. C. (2016). May selective serotonin reuptake inhibitors (SSRIs) provide some benefit for the treatment of schizophrenia? Expert Opin Pharmacother 17, 1375-85.

Cai, N., Kendler, K. \& Flint, J. J. B. (2018). Minimal phenotyping yields GWAS hits of low specificity for major depression. 440735 .

Choi, S. W., Mak, T. S. H. \& O'reilly, P. J. B. (2018). A guide to performing Polygenic Risk Score analyses. 416545.

Choi, S. W. \& O'Reilly, P. F. (2019). PRSice-2: Polygenic Risk Score software for biobank-scale data. Gigascience $\mathbf{8}$.

Crown, W. H., Finkelstein, S., Berndt, E. R., Ling, D., Poret, A. W., Rush, A. J. \& Russell, J. M. (2002). The impact of treatment-resistant depression on health care utilization and costs. J Clin Psychiatry 63, 963-71.

De Carlo, V., Calati, R. \& Serretti, A. (2016). Socio-demographic and clinical predictors of nonresponse/non-remission in treatment resistant depressed patients: A systematic review. Psychiatry Res 240, 421-430.

Dold, M., Bartova, L., Mendlewicz, J., Souery, D., Serretti, A., Porcelli, S., Zohar, J., Montgomery, S. \& Kasper, S. (2018). Clinical correlates of augmentation/combination treatment strategies in major depressive disorder. Acta Psychiatr Scand 137, 401-412.

Dudbridge, F. (2013). Power and predictive accuracy of polygenic risk scores. PLoS Genet 9, e1003348.

Fabbri, C., Kasper, S., Kautzky, A., Bartova, L., Dold, M., Zohar, J., Souery, D., Montgomery, S., Albani, D., Raimondi, I., Dikeos, D., Rujescu, D., Uher, R., Lewis, C. M., Mendlewicz, J. \& Serretti, A. (2019). Genome-wide association study of treatment-resistance in depression and meta-analysis of three independent samples. Br J Psychiatry 214, 36-41.

Fond, G., Hamdani, N., Kapczinski, F., Boukouaci, W., Drancourt, N., Dargel, A., Oliveira, J., Le Guen, E., Marlinge, E., Tamouza, R. \& Leboyer, M. (2014). Effectiveness and tolerance of 
anti-inflammatory drugs' add-on therapy in major mental disorders: a systematic qualitative review. Acta Psychiatr Scand 129, 163-79.

Foo, J. C., Streit, F., Frank, J., Witt, S. H., Treutlein, J., Major Depressive Disorder Working Group of the Psychiatric Genomics, C., Baune, B. T., Moebus, S., Jockel, K. H., Forstner, A. J., Nothen, M. M., Rietschel, M., Sartorius, A. \& Kranaster, L. (2019). Evidence for increased genetic risk load for major depression in patients assigned to electroconvulsive therapy. Am J Med Genet B Neuropsychiatr Genet 180, 35-45.

Garcia-Gonzalez, J., Tansey, K. E., Hauser, J., Henigsberg, N., Maier, W., Mors, O., Placentino, A., Rietschel, M., Souery, D., Zagar, T., Czerski, P. M., Jerman, B., Buttenschon, H. N., Schulze, T. G., Zobel, A., Farmer, A., Aitchison, K. J., Craig, I., McGuffin, P., Giupponi, M., Perroud, N., Bondolfi, G., Evans, D., O'Donovan, M., Peters, T. J., Wendland, J. R., Lewis, G., Kapur, S., Perlis, R., Arolt, V., Domschke, K., Major Depressive Disorder Working Group of the Psychiatric Genomic, C., Breen, G., Curtis, C., Sang-Hyuk, L., Kan, C., Newhouse, S., Patel, H., Baune, B. T., Uher, R., Lewis, C. M. \& Fabbri, C. (2017). Pharmacogenetics of antidepressant response: A polygenic approach. Prog Neuropsychopharmacol Biol Psychiatry 75, 128-134.

Genetics of Personality, C., de Moor, M. H., van den Berg, S. M., Verweij, K. J., Krueger, R. F., Luciano, M., Arias Vasquez, A., Matteson, L. K., Derringer, J., Esko, T., Amin, N., Gordon, S. D., Hansell, N. K., Hart, A. B., Seppala, I., Huffman, J. E., Konte, B., Lahti, J., Lee, M., Miller, M., Nutile, T., Tanaka, T., Teumer, A., Viktorin, A., Wedenoja, J., Abecasis, G. R., Adkins, D. E., Agrawal, A., Allik, J., Appel, K., Bigdeli, T. B., Busonero, F., Campbell, H., Costa, P. T., Davey Smith, G., Davies, G., de Wit, H., Ding, J., Engelhardt, B. E., Eriksson, J. G., Fedko, I. O., Ferrucci, L., Franke, B., Giegling, I., Grucza, R., Hartmann, A. M., Heath, A. C., Heinonen, K., Henders, A. K., Homuth, G., Hottenga, J. J., Iacono, W. G., Janzing, J., Jokela, M., Karlsson, R., Kemp, J. P., Kirkpatrick, M. G., Latvala, A., Lehtimaki, T., Liewald, D. C., Madden, P. A., Magri, C., Magnusson, P. K., Marten, J., Maschio, A., Medland, S. E., Mihailov, E., Milaneschi, Y., Montgomery, G. W., Nauck, M., Ouwens, K. G., Palotie, A., Pettersson, E., Polasek, O., Qian, Y., Pulkki-Raback, L., Raitakari, O. T., Realo, A., Rose, R. J., Ruggiero, D., Schmidt, C. O., Slutske, W. S., Sorice, R., Starr, J. M., St Pourcain, B., Sutin, A. R., Timpson, N. J., Trochet, H., Vermeulen, S., Vuoksimaa, E., Widen, E., Wouda, J., Wright, M. J., Zgaga, L., Porteous, D., Minelli, A., Palmer, A. A., Rujescu, D., Ciullo, M., Hayward, C., Rudan, I., Metspalu, A., Kaprio, J., Deary, I. J., Raikkonen, K., Wilson, J. F., Keltikangas-Jarvinen, L., Bierut, L. J., Hettema, J. M., Grabe, H. J., van Duijn, C. M., Evans, D. M., Schlessinger, D., Pedersen, N. L., Terracciano, A., McGue, M., Penninx, B. W., Martin, N. G. \& Boomsma, D. I. (2015). Meta-analysis of Genome-wide Association Studies for Neuroticism, and the Polygenic Association With Major Depressive Disorder. JAMA Psychiatry 72, 642-50.

Greenberg, P. E., Fournier, A. A., Sisitsky, T., Pike, C. T. \& Kessler, R. C. (2015). The economic burden of adults with major depressive disorder in the United States (2005 and 2010). $J$ Clin Psychiatry 76, 155-62.

Halldorsdottir, T., Piechaczek, C., Soares de Matos, A. P., Czamara, D., Pehl, V., Wagenbuechler, P., Feldmann, L., Quickenstedt-Reinhardt, P., Allgaier, A. K., Freisleder, F. J., Greimel, E., Kvist, T., Lahti, J., Raikkonen, K., Rex-Haffner, M., Arnarson, E. O., Craighead, W. E., Schulte-Korne, G. \& Binder, E. B. (2019). Polygenic Risk: Predicting Depression Outcomes in Clinical and Epidemiological Cohorts of Youths. Am J Psychiatry 176, 615-625.

Howard, D. M., Adams, M. J., Shirali, M., Clarke, T. K., Marioni, R. E., Davies, G., Coleman, J. R. I., Alloza, C., Shen, X., Barbu, M. C., Wigmore, E. M., Gibson, J., andMe Research, T., Hagenaars, S. P., Lewis, C. M., Ward, J., Smith, D. J., Sullivan, P. F., Haley, C. S., Breen, G., Deary, I. J. \& McIntosh, A. M. (2018). Genome-wide association study of depression phenotypes in UK Biobank identifies variants in excitatory synaptic pathways. Nat Commun 9, 1470. 
International Consortium on Lithium, G., Amare, A. T., Schubert, K. O., Hou, L., Clark, S. R., Papiol, S., Heilbronner, U., Degenhardt, F., Tekola-Ayele, F., Hsu, Y. H., Shekhtman, T., Adli, M., Akula, N., Akiyama, K., Ardau, R., Arias, B., Aubry, J. M., Backlund, L., Bhattacharjee, A. K., Bellivier, F., Benabarre, A., Bengesser, S., Biernacka, J. M., Birner, A., Brichant-Petitjean, C., Cervantes, P., Chen, H. C., Chillotti, C., Cichon, S., Cruceanu, C., Czerski, P. M., Dalkner, N., Dayer, A., Del Zompo, M., DePaulo, J. R., Etain, B., Falkai, P., Forstner, A. J., Frisen, L., Frye, M. A., Fullerton, J. M., Gard, S., Garnham, J. S., Goes, F. S., Grigoroiu-Serbanescu, M., Grof, P., Hashimoto, R., Hauser, J., Herms, S., Hoffmann, P., Hofmann, A., Jamain, S., Jimenez, E., Kahn, J. P., Kassem, L., Kuo, P. H., Kato, T., Kelsoe, J., Kittel-Schneider, S., Kliwicki, S., Konig, B., Kusumi, I., Laje, G., Landen, M., Lavebratt, C., Leboyer, M., Leckband, S. G., Tortorella, A., Manchia, M., Martinsson, L., McCarthy, M. J., McElroy, S., Colom, F., Mitjans, M., Mondimore, F. M., Monteleone, P., Nievergelt, C. M., Nothen, M. M., Novak, T., O'Donovan, C., Ozaki, N., Osby, U., Pfennig, A., Potash, J. B., Reif, A., Reininghaus, E., Rouleau, G. A., Rybakowski, J. K., Schalling, M., Schofield, P. R., Schweizer, B. W., Severino, G., Shilling, P. D., Shimoda, K., Simhandl, C., Slaney, C. M., Squassina, A., Stamm, T., Stopkova, P., Maj, M., Turecki, G., Vieta, E., Volkert, J., Witt, S., Wright, A., Zandi, P. P., Mitchell, P. B., Bauer, M., Alda, M., Rietschel, M., McMahon, F. J., Schulze, T. G. \& Baune, B. T. (2018). Association of Polygenic Score for Schizophrenia and HLA Antigen and Inflammation Genes With Response to Lithium in Bipolar Affective Disorder: A Genome-Wide Association Study. JAMA Psychiatry 75, 65-74.

Kautzky, A., Baldinger, P., Souery, D., Montgomery, S., Mendlewicz, J., Zohar, J., Serretti, A., Lanzenberger, R. \& Kasper, S. (2015). The combined effect of genetic polymorphisms and clinical parameters on treatment outcome in treatment-resistant depression. Eur Neuropsychopharmacol 25, 441-53.

Kautzky, A., Dold, M., Bartova, L., Spies, M., Kranz, G. S., Souery, D., Montgomery, S., Mendlewicz, J., Zohar, J., Fabbri, C., Serretti, A., Lanzenberger, R., Dikeos, D., Rujescu, D. \& Kasper, S. (2019). Clinical factors predicting treatment resistant depression: affirmative results from the European multicenter study. Acta Psychiatr Scand 139, 78-88.

Kautzky, A., Dold, M., Bartova, L., Spies, M., Vanicek, T., Souery, D., Montgomery, S., Mendlewicz, J., Zohar, J., Fabbri, C., Serretti, A., Lanzenberger, R. \& Kasper, S. (2018). Refining Prediction in Treatment-Resistant Depression: Results of Machine Learning Analyses in the TRD III Sample. J Clin Psychiatry 79.

Khera, A. V., Chaffin, M., Aragam, K. G., Haas, M. E., Roselli, C., Choi, S. H., Natarajan, P., Lander, E. S., Lubitz, S. A., Ellinor, P. T. \& Kathiresan, S. (2018). Genome-wide polygenic scores for common diseases identify individuals with risk equivalent to monogenic mutations. Nat Genet 50, 1219-1224.

Kim, Y. K. \& Na, K. S. (2016). Role of glutamate receptors and glial cells in the pathophysiology of treatment-resistant depression. Prog Neuropsychopharmacol Biol Psychiatry 70, 117-26.

Kullo, I. J., Jouni, H., Austin, E. E., Brown, S. A., Kruisselbrink, T. M., Isseh, I. N., Haddad, R. A., Marroush, T. S., Shameer, K., Olson, J. E., Broeckel, U., Green, R. C., Schaid, D. J., Montori, V. M. \& Bailey, K. R. (2016). Incorporating a Genetic Risk Score Into Coronary Heart Disease Risk Estimates: Effect on Low-Density Lipoprotein Cholesterol Levels (the MI-GENES Clinical Trial). Circulation 133, 1181-8.

Li, Y., Willer, C. J., Ding, J., Scheet, P. \& Abecasis, G. R. (2010). MaCH: using sequence and genotype data to estimate haplotypes and unobserved genotypes. Genet Epidemiol 34, 816-34.

Montgomery, S. A. \& Åsberg, M. J. T. B. j. o. p. (1979). A new depression scale designed to be sensitive to change. 134, 382-389.

Mrazek, D. A., Hornberger, J. C., Altar, C. A. \& Degtiar, I. (2014). A review of the clinical, economic, and societal burden of treatment-resistant depression: 1996-2013. Psychiatr Serv 65, 977-87. 
Niculescu, A. B., Levey, D. F., Phalen, P. L., Le-Niculescu, H., Dainton, H. D., Jain, N., Belanger, E., James, A., George, S., Weber, H., Graham, D. L., Schweitzer, R., Ladd, T. B., Learman, R., Niculescu, E. M., Vanipenta, N. P., Khan, F. N., Mullen, J., Shankar, G., Cook, S., Humbert, C., Ballew, A., Yard, M., Gelbart, T., Shekhar, A., Schork, N. J., Kurian, S. M., Sandusky, G. E. \& Salomon, D. R. (2015). Understanding and predicting suicidality using a combined genomic and clinical risk assessment approach. Mol Psychiatry 20, 1266-85.

Niitsu, T., Fabbri, C., Bentini, F. \& Serretti, A. (2013). Pharmacogenetics in major depression: a comprehensive meta-analysis. Prog Neuropsychopharmacol Biol Psychiatry 45, 183-94.

Palla, L. \& Dudbridge, F. (2015). A Fast Method that Uses Polygenic Scores to Estimate the Variance Explained by Genome-wide Marker Panels and the Proportion of Variants Affecting a Trait. Am J Hum Genet 97, 250-9.

Patterson, N., Price, A. L. \& Reich, D. (2006). Population structure and eigenanalysis. PLoS Genet 2, e190.

Schizophrenia Working Group of the Psychiatric Genomics, C. (2014). Biological insights from 108 schizophrenia-associated genetic loci. Nature 511, 421-7.

Sheehan, D. V., Lecrubier, Y., Sheehan, K. H., Amorim, P., Janavs, J., Weiller, E., Hergueta, T., Baker, R. \& Dunbar, G. C. (1998). The Mini-International Neuropsychiatric Interview (M.I.N.I.): the development and validation of a structured diagnostic psychiatric interview for DSM-IV and ICD-10. J Clin Psychiatry 59 Suppl 20, 22-33;quiz 34-57.

Stahl, E. A., Breen, G., Forstner, A. J., McQuillin, A., Ripke, S., Trubetskoy, V., Mattheisen, M., Wang, Y., Coleman, J. R. I., Gaspar, H. A., de Leeuw, C. A., Steinberg, S., Pavlides, J. M. W., Trzaskowski, M., Byrne, E. M., Pers, T. H., Holmans, P. A., Richards, A. L., Abbott, L., Agerbo, E., Akil, H., Albani, D., Alliey-Rodriguez, N., Als, T. D., Anjorin, A., Antilla, V., Awasthi, S., Badner, J. A., Baekvad-Hansen, M., Barchas, J. D., Bass, N., Bauer, M., Belliveau, R., Bergen, S. E., Pedersen, C. B., Boen, E., Boks, M. P., Boocock, J., Budde, M., Bunney, W., Burmeister, M., Bybjerg-Grauholm, J., Byerley, W., Casas, M., Cerrato, F., Cervantes, P., Chambert, K., Charney, A. W., Chen, D., Churchhouse, C., Clarke, T. K., Coryell, W., Craig, D. W., Cruceanu, C., Curtis, D., Czerski, P. M., Dale, A. M., de Jong, S., Degenhardt, F., Del-Favero, J., DePaulo, J. R., Djurovic, S., Dobbyn, A. L., Dumont, A., Elvsashagen, T., Escott-Price, V., Fan, C. C., Fischer, S. B., Flickinger, M., Foroud, T. M., Forty, L., Frank, J., Fraser, C., Freimer, N. B., Frisen, L., Gade, K., Gage, D., Garnham, J., Giambartolomei, C., Pedersen, M. G., Goldstein, J., Gordon, S. D., Gordon-Smith, K., Green, E. K., Green, M. J., Greenwood, T. A., Grove, J., Guan, W., Guzman-Parra, J., Hamshere, M. L., Hautzinger, M., Heilbronner, U., Herms, S., Hipolito, M., Hoffmann, P., Holland, D., Huckins, L., Jamain, S., Johnson, J. S., Jureus, A., Kandaswamy, R., Karlsson, R., Kennedy, J. L., Kittel-Schneider, S., Knowles, J. A., Kogevinas, M., Koller, A. C., Kupka, R., Lavebratt, C., Lawrence, J., Lawson, W. B., Leber, M., Lee, P. H., Levy, S. E., Li, J. Z., Liu, C., Lucae, S., Maaser, A., MacIntyre, D. J., Mahon, P. B., Maier, W., Martinsson, L., McCarroll, S., McGuffin, P., McInnis, M. G., McKay, J. D., Medeiros, H., Medland, S. E., Meng, F., Milani, L., Montgomery, G. W., Morris, D. W., Muhleisen, T. W., Mullins, N., Nguyen, H., Nievergelt, C. M., Adolfsson, A. N., Nwulia, E. A., O'Donovan, C., Loohuis, L. M. O., Ori, A. P. S., Oruc, L., Osby, U., Perlis, R. H., Perry, A., Pfennig, A., Potash, J. B., Purcell, S. M., Regeer, E. J., Reif, A., Reinbold, C. S., Rice, J. P., Rivas, F., Rivera, M., Roussos, P., Ruderfer, D. M., Ryu, E., Sanchez-Mora, C., Schatzberg, A. F., Scheftner, W. A., Schork, N. J., Shannon Weickert, C., Shehktman, T., Shilling, P. D., Sigurdsson, E., Slaney, C., Smeland, O. B., Sobell, J. L., Soholm Hansen, C., Spijker, A. T., St Clair, D., Steffens, M., Strauss, J. S., Streit, F., Strohmaier, J., Szelinger, S., Thompson, R. C., Thorgeirsson, T. E., Treutlein, J., Vedder, H., Wang, W., Watson, S. J., Weickert, T. W., Witt, S. H., Xi, S., Xu, W., Young, A. H., Zandi, P., Zhang, P., Zollner, S., e, Q. C., Consortium, B., Adolfsson, R., Agartz, I., Alda, M., Backlund, L., Baune, B. T., Bellivier, F., Berrettini, W. H., Biernacka, J. M., Blackwood, D. H. R., Boehnke, M., Borglum, A. D., Corvin, A., Craddock, N., Daly, M. J., Dannlowski, U., Esko, T., 
Etain, B., Frye, M., Fullerton, J. M., Gershon, E. S., Gill, M., Goes, F., Grigoroiu-Serbanescu, M., Hauser, J., Hougaard, D. M., Hultman, C. M., Jones, I., Jones, L. A., Kahn, R. S., Kirov, G., Landen, M., Leboyer, M., Lewis, C. M., Li, Q. S., Lissowska, J., Martin, N. G., Mayoral, F., McElroy, S. L., McIntosh, A. M., McMahon, F. J., Melle, I., Metspalu, A., Mitchell, P. B., Morken, G., Mors, O., Mortensen, P. B., Muller-Myhsok, B., Myers, R. M., Neale, B. M., Nimgaonkar, V., Nordentoft, M., Nothen, M. M., O'Donovan, M. C., Oedegaard, K. J., Owen, M. J., Paciga, S. A., Pato, C., Pato, M. T., Posthuma, D., Ramos-Quiroga, J. A., Ribases, M., Rietschel, M., Rouleau, G. A., Schalling, M., Schofield, P. R., Schulze, T. G., Serretti, A., Smoller, J. W., Stefansson, H., Stefansson, K., Stordal, E., Sullivan, P. F., Turecki, G., Vaaler, A. E., Vieta, E., Vincent, J. B., Werge, T., Nurnberger, J. I., Wray, N. R., Di Florio, A., Edenberg, H. J., Cichon, S., Ophoff, R. A., Scott, L. J., Andreassen, O. A., Kelsoe, J., Sklar, P. \& Bipolar Disorder Working Group of the Psychiatric Genomics, C. (2019). Genome-wide association study identifies 30 loci associated with bipolar disorder. Nat Genet 51, 793-803.

Tansey, K. E., Guipponi, M., Domenici, E., Lewis, G., Malafosse, A., O'Donovan, M., Wendland, J. R., Lewis, C. M., McGuffin, P. \& Uher, R. (2014). Genetic susceptibility for bipolar disorder and response to antidepressants in major depressive disorder. Am J Med Genet B Neuropsychiatr Genet 165B, 77-83.

Tansey, K. E., Guipponi, M., Hu, X., Domenici, E., Lewis, G., Malafosse, A., Wendland, J. R., Lewis, C. M., McGuffin, P. \& Uher, R. (2013). Contribution of common genetic variants to antidepressant response. Biol Psychiatry 73, 679-82.

Ward, J., Graham, N., Strawbridge, R. J., Ferguson, A., Jenkins, G., Chen, W., Hodgson, K., Frye, M., Weinshilboum, R., Uher, R., Lewis, C. M., Biernacka, J. \& Smith, D. J. (2018). Polygenic risk scores for major depressive disorder and neuroticism as predictors of antidepressant response: Meta-analysis of three treatment cohorts. PLoS One 13, e0203896.

Watanabe, K., Stringer, S., Frei, O., Umicevic Mirkov, M., de Leeuw, C., Polderman, T. J. C., van der Sluis, S., Andreassen, O. A., Neale, B. M. \& Posthuma, D. (2019). A global overview of pleiotropy and genetic architecture in complex traits. Nat Genet 51, 1339-1348.

Whalley, H. C., Adams, M. J., Hall, L. S., Clarke, T. K., Fernandez-Pujals, A. M., Gibson, J., Wigmore, E., Hafferty, J., Hagenaars, S. P., Davies, G., Campbell, A., Hayward, C., Lawrie, S. M., Porteous, D. J., Deary, I. J. \& McIntosh, A. M. (2016). Dissection of major depressive disorder using polygenic risk scores for schizophrenia in two independent cohorts. Transl Psychiatry 6, e938.

WHO (2017). Depression and other common mental disorders: global health estimates. World Health Organization.

Wigmore, E. M., Hafferty, J. D., Hall, L. S., Howard, D. M., Clarke, T. K., Fabbri, C., Lewis, C. M., Uher, R., Navrady, L. B., Adams, M. J., Zeng, Y., Campbell, A., Gibson, J., Thomson, P. A., Hayward, C., Smith, B. H., Hocking, L. J., Padmanabhan, S., Deary, I. J., Porteous, D. J., Mors, O., Mattheisen, M., Nicodemus, K. K. \& McIntosh, A. M. (2019). Genome-wide association study of antidepressant treatment resistance in a population-based cohort using health service prescription data and meta-analysis with GENDEP. Pharmacogenomics $J$.

Wray, N. R., Goddard, M. E. \& Visscher, P. M. (2007). Prediction of individual genetic risk to disease from genome-wide association studies. Genome Res 17, 1520-8.

Wray, N. R., Goddard, M. E. \& Visscher, P. M. (2008). Prediction of individual genetic risk of complex disease. Curr Opin Genet Dev 18, 257-63.

Wray, N. R., Ripke, S., Mattheisen, M., Trzaskowski, M., Byrne, E. M., Abdellaoui, A., Adams, M. J., Agerbo, E., Air, T. M., Andlauer, T. M. F., Bacanu, S. A., Baekvad-Hansen, M., Beekman, A. F. T., Bigdeli, T. B., Binder, E. B., Blackwood, D. R. H., Bryois, J., Buttenschon, H. N., Bybjerg-Grauholm, J., Cai, N., Castelao, E., Christensen, J. H., Clarke, T. K., Coleman, J. I. R., Colodro-Conde, L., Couvy-Duchesne, B., Craddock, N., Crawford, G. E., Crowley, C. A., Dashti, H. S., Davies, G., Deary, I. J., Degenhardt, F., Derks, E. M., Direk, N., Dolan, C. V., Dunn, E. C., Eley, T. C., Eriksson, N., Escott-Price, V., Kiadeh, F. H. F., 
Finucane, H. K., Forstner, A. J., Frank, J., Gaspar, H. A., Gill, M., Giusti-Rodriguez, P., Goes, F. S., Gordon, S. D., Grove, J., Hall, L. S., Hannon, E., Hansen, C. S., Hansen, T. F., Herms, S., Hickie, I. B., Hoffmann, P., Homuth, G., Horn, C., Hottenga, J. J., Hougaard, D. M., Hu, M., Hyde, C. L., Ising, M., Jansen, R., Jin, F., Jorgenson, E., Knowles, J. A., Kohane, I. S., Kraft, J., Kretzschmar, W. W., Krogh, J., Kutalik, Z., Lane, J. M., Li, Y., Li, Y., Lind, P. A., Liu, X., Lu, L., MacIntyre, D. J., MacKinnon, D. F., Maier, R. M., Maier, W., Marchini, J., Mbarek, H., McGrath, P., McGuffin, P., Medland, S. E., Mehta, D., Middeldorp, C. M., Mihailov, E., Milaneschi, Y., Milani, L., Mill, J., Mondimore, F. M., Montgomery, G. W., Mostafavi, S., Mullins, N., Nauck, M., Ng, B., Nivard, M. G., Nyholt, D. R., O'Reilly, P. F., Oskarsson, H., Owen, M. J., Painter, J. N., Pedersen, C. B., Pedersen, M. G., Peterson, R. E., Pettersson, E., Peyrot, W. J., Pistis, G., Posthuma, D., Purcell, S. M., Quiroz, J. A., Qvist, P., Rice, J. P., Riley, B. P., Rivera, M., Saeed Mirza, S., Saxena, R., Schoevers, R., Schulte, E. C., Shen, L., Shi, J., Shyn, S. I., Sigurdsson, E., Sinnamon, G. B. C., Smit, J. H., Smith, D. J., Stefansson, H., Steinberg, S., Stockmeier, C. A., Streit, F., Strohmaier, J., Tansey, K. E., Teismann, H., Teumer, A., Thompson, W., Thomson, P. A., Thorgeirsson, T. E., Tian, C., Traylor, M., Treutlein, J., Trubetskoy, V., Uitterlinden, A. G., Umbricht, D., Van der Auwera, S., van Hemert, A. M., Viktorin, A., Visscher, P. M., Wang, Y., Webb, B. T., Weinsheimer, S. M., Wellmann, J., Willemsen, G., Witt, S. H., Wu, Y., Xi, H. S., Yang, J., Zhang, F., eQtlgen, andMe, Arolt, V., Baune, B. T., Berger, K., Boomsma, D. I., Cichon, S., Dannlowski, U., de Geus, E. C. J., DePaulo, J. R., Domenici, E., Domschke, K., Esko, T., Grabe, H. J., Hamilton, S. P., Hayward, C., Heath, A. C., Hinds, D. A., Kendler, K. S., Kloiber, S., Lewis, G., Li, Q. S., Lucae, S., Madden, P. F. A., Magnusson, P. K., Martin, N. G., McIntosh, A. M., Metspalu, A., Mors, O., Mortensen, P. B., Muller-Myhsok, B., Nordentoft, M., Nothen, M. M., O'Donovan, M. C., Paciga, S. A., Pedersen, N. L., Penninx, B., Perlis, R. H., Porteous, D. J., Potash, J. B., Preisig, M., Rietschel, M., Schaefer, C., Schulze, T. G., Smoller, J. W., Stefansson, K., Tiemeier, H., Uher, R., Volzke, H., Weissman, M. M., Werge, T., Winslow, A. R., Lewis, C. M., Levinson, D. F., Breen, G., Borglum, A. D., Sullivan, P. F. \& Major Depressive Disorder Working Group of the Psychiatric Genomics, C. (2018). Genomewide association analyses identify 44 risk variants and refine the genetic architecture of major depression. Nat Genet 50, 668-681.

Zhang, J. P., Robinson, D., Yu, J., Gallego, J., Fleischhacker, W. W., Kahn, R. S., CrespoFacorro, B., Vazquez-Bourgon, J., Kane, J. M., Malhotra, A. K. \& Lencz, T. (2019). Schizophrenia Polygenic Risk Score as a Predictor of Antipsychotic Efficacy in First-Episode Psychosis. Am J Psychiatry 176, 21-28. 


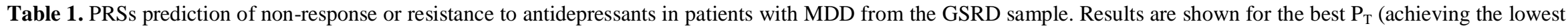

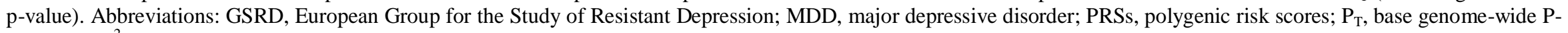
threshold; $\mathrm{R}^{2}$, the proportion of phenotypic variance explained; SE, standard error; SNPs, single-nucleotide polymorphisms.

$*$ Nominally significant results ( $\mathrm{p}$-value $<0.05$ ).

\begin{tabular}{|c|c|c|c|c|c|c|c|c|c|}
\hline Base trait & $\begin{array}{l}\text { Base sample } \\
\text { (sample size) }\end{array}$ & $\begin{array}{l}\text { Phenotype } \\
\text { outcome }\end{array}$ & Best $\mathbf{P}_{\mathrm{T}}$ & $\begin{array}{c}\text { No. of SNPs at } \\
\text { the best } P_{T}\end{array}$ & PRS $R^{2}$ & $\begin{array}{l}\text { Estimate } \\
\text { (SE) }\end{array}$ & z-value & p-value & $\begin{array}{c}\text { Empirical } \\
\text { p-value }\left(p_{E}\right)\end{array}$ \\
\hline \multirow{2}{*}{ Bipolar disorder } & \multirow{2}{*}{$\begin{array}{l}\text { Stahl et al. } 2019 \\
\quad(\mathrm{n}=51,710)\end{array}$} & $\begin{array}{l}\text { response vs. non- } \\
\text { response }\end{array}$ & 0.1 & 87,253 & 0.004 & $\begin{array}{c}0.158 \\
(0.103)\end{array}$ & 1.539 & 0.124 & 0.399 \\
\hline & & $\begin{array}{l}\text { response vs. } \\
\text { resistance }\end{array}$ & 0.2 & 143,443 & 0.003 & $\begin{array}{c}0.134 \\
(0.102)\end{array}$ & 1.314 & 0.189 & 0.544 \\
\hline \multirow{2}{*}{$\begin{array}{c}\text { Major depressive } \\
\text { disorder }\end{array}$} & \multirow{2}{*}{$\begin{array}{c}\text { Wray et al., } 2018+ \\
\text { Howard et al., } \\
2018 \\
(\mathrm{n}=500,199)\end{array}$} & $\begin{array}{l}\text { response vs. non- } \\
\text { response }\end{array}$ & 0.1 & 84,468 & 0.009 & $\begin{array}{c}0.185 \\
(0.086)\end{array}$ & 2.150 & $0.032 *$ & 0.101 \\
\hline & & $\begin{array}{l}\text { response vs. } \\
\text { resistance }\end{array}$ & 0.001 & 3,991 & 0.003 & $\begin{array}{c}0.124 \\
(0.083)\end{array}$ & 1.485 & 0.137 & 0.378 \\
\hline \multirow{2}{*}{ Schizophrenia } & \multirow{2}{*}{$\begin{array}{l}\text { Ripke et al., } 2014 \\
\quad(\mathrm{n}=150,064)\end{array}$} & $\begin{array}{l}\text { response vs. non- } \\
\text { response }\end{array}$ & 0.1 & 85,400 & 0.016 & $\begin{array}{c}0.312 \\
(0.105)\end{array}$ & 2.963 & $0.003 *$ & $0.014 *$ \\
\hline & & $\begin{array}{l}\text { response vs. } \\
\text { resistance }\end{array}$ & 0.1 & 85,427 & 0.001 & $\begin{array}{c}0.093 \\
(0.104)\end{array}$ & 0.898 & 0.369 & 0.720 \\
\hline \multirow{2}{*}{ Neuroticism } & \multirow{2}{*}{$\begin{array}{l}\text { Baselmans et al., } \\
2019(\mathrm{n}=523,783)\end{array}$} & $\begin{array}{l}\text { response vs. non- } \\
\text { response }\end{array}$ & 0.5 & 92,631 & 0.002 & $\begin{array}{l}-0.095 \\
(0.085)\end{array}$ & -1.120 & 0.263 & 0.601 \\
\hline & & $\begin{array}{l}\text { response vs. } \\
\text { resistance }\end{array}$ & 0.001 & 3,143 & 0.006 & $\begin{array}{c}0.165 \\
(0.084)\end{array}$ & 1.970 & $0.049 *$ & 0.154 \\
\hline
\end{tabular}


Table 2. Association of SCZ-PRSs with clinical and socio-demographic characteristics among responders and nonresponders MDD patients from the GSRD sample. The fractions express the ratio of patients with and without the considered specific attribute. Abbreviations: SCZ, schizophrenia; PRS, Polygenic Risk Score; Q1, lowest SCZ-PRS quintile; Q5, upper SCZ-PRS quintile; SGA, second generation antipsychotics; MADRS, Montgomery-Åsberg Depression Rating Scale; MDD, major depressive disorder; BD, bipolar disorder; OCD, obsessive-compulsive disorder; PTSD, post-traumatic stress disorder.

${ }^{\text {a }}$ Fisher's exact test

*p-value $<0.05$

\begin{tabular}{|c|c|c|c|c|}
\hline & $\begin{array}{c}\text { Lowest SCZ-PRS } \\
(\mathrm{Q} 1)\end{array}$ & $\begin{array}{l}\text { Highest SCZ- } \\
\text { PRS (Q5) }\end{array}$ & Statistics & p-value \\
\hline Augmentation with SGA, no/yes & $106 / 28$ & $85 / 49$ & $\chi^{2}=7.289$ & $0.007 *$ \\
\hline $\begin{array}{l}\text { Outcome MADRS indifferently } \\
\text { from augmentation with SGA, } \\
\text { responders/non-responders }\end{array}$ & $62 / 72$ & $43 / 91$ & $\chi^{2}=5.073$ & $0.024 *$ \\
\hline $\begin{array}{l}\text { Outcome MADRS in patients who } \\
\text { received augmentation with SGA, } \\
\text { responders/non-responders }\end{array}$ & $9 / 19$ & $18 / 33$ & $\chi^{2}=0.001$ & 0.972 \\
\hline $\begin{array}{l}\text { Outcome MADRS in patients who } \\
\text { did not receive augmentation with } \\
\text { SGA, } \\
\text { responders/non-responders }\end{array}$ & $53 / 53$ & $25 / 58$ & $\chi^{2}=6.792$ & $0.009 *$ \\
\hline Psychotic features, no/yes & $93 / 1$ & $105 / 7$ & - & $0.073^{\mathrm{a}}$ \\
\hline Living with a partner, no/yes & $55 / 79$ & $74 / 60$ & $\chi^{2}=4.842$ & $0.028 *$ \\
\hline Employment status, no/yes & $25 / 108$ & $48 / 85$ & $\chi^{2}=9.138$ & $0.003 *$ \\
\hline Family history for MDD, no/yes & $73 / 50$ & $75 / 51$ & $\chi^{2}=0.01$ & 0.919 \\
\hline Family history for BD, no/yes & $116 / 6$ & $116 / 7$ & - & $1.000^{\mathrm{a}}$ \\
\hline Any family history, no/yes & $96 / 31$ & $96 / 24$ & $\chi^{2}=0.462$ & 0.497 \\
\hline $\begin{array}{l}\text { Family history for SCZ-spectrum } \\
\text { disorders, no/yes }\end{array}$ & $123 / 4$ & $113 / 7$ & - & $0.365^{\mathrm{a}}$ \\
\hline Family history for suicide, no/yes & $110 / 19$ & $122 / 8$ & - & $0.026^{\mathrm{a} *}$ \\
\hline $\begin{array}{l}\text { Family history for suicide attempts, } \\
\text { no/yes }\end{array}$ & $113 / 16$ & $119 / 6$ & - & $0.043^{\mathrm{a} *}$ \\
\hline $\begin{array}{l}\text { Number of depressive episodes, } \\
\text { mean (SD) }\end{array}$ & $3.11(2.16)$ & $4.12(3.10)$ & $\mathrm{t}=-2.819$ & $0.005^{\mathrm{a} *}$ \\
\hline Age at onset (years), mean (SD) & $35.45(15.25)$ & $36.22(14.20)$ & $\mathrm{t}=-0.411$ & $0.682^{a}$ \\
\hline $\begin{array}{l}\text { Length of hospitalisation (days), } \\
\text { mean (SD) }\end{array}$ & $5.89(19.06)$ & $5.38(14.44)$ & $\mathrm{t}=0.237$ & $0.813^{\mathrm{a}}$ \\
\hline Melancholia, no/yes & $32 / 100$ & $46 / 86$ & $\chi^{2}=3.075$ & 0.079 \\
\hline Suicidality, no/yes & $81 / 53$ & $66 / 68$ & $\chi^{2}=2.953$ & 0.086 \\
\hline Agoraphobia, no/yes & $121 / 11$ & $123 / 7$ & - & $0.465^{\mathrm{a}}$ \\
\hline Social phobia, no/yes & $129 / 5$ & $130 / 9$ & - & $0.413^{\mathrm{a}}$ \\
\hline OCD, no/yes & $134 / 0$ & $127 / 4$ & - & $0.058^{\mathrm{a}}$ \\
\hline PTSD, no/yes & $133 / 1$ & $133 / 1$ & - & $1.000^{\mathrm{a}}$ \\
\hline GAD, no/yes & $122 / 12$ & $113 / 21$ & $\chi^{2}=2.212$ & 0.137 \\
\hline $\begin{array}{l}\text { Duration of current episode (days), } \\
\text { mean (SD) }\end{array}$ & $166.97(182.33)$ & $185.95(175.00)$ & $\mathrm{t}=-0.811$ & 0.418 \\
\hline $\begin{array}{l}\text { Baseline MADRS score, } \\
\text { mean (SD) }\end{array}$ & $32.22(7.55)$ & $35.08(7.87)$ & $\mathrm{t}=3.033$ & $0.003 *$ \\
\hline $\begin{array}{l}\text { Current MADRS score, } \\
\text { mean (SD) }\end{array}$ & $17.91(11.18)$ & $22.71(10.48)$ & $\mathrm{t}=-3.625$ & $3.5 \mathrm{e}-4 *$ \\
\hline
\end{tabular}


medRxiv preprint doi: https://doi.org/10.1101/2020.01.15.20017699; this version posted January 18, 2020. The copyright holder for this preprint (which was not certified by peer review) is the author/funder, who has granted medRxiv a license to display the preprint in perpetuity.

All rights reserved. No reuse allowed without permission.

Figure 1a. Bar plot showing the association between SCZ-PRSs and non-response to antidepressants; x-axis: GWAS p thresholds $\left(\mathrm{P}_{\mathrm{T}}\right)$ used for PRSs calculation; y-axis: Nagelkerke's pseudo- $\mathrm{R}^{2}$. Nominal significance level $=\mathrm{p}<0.05$.

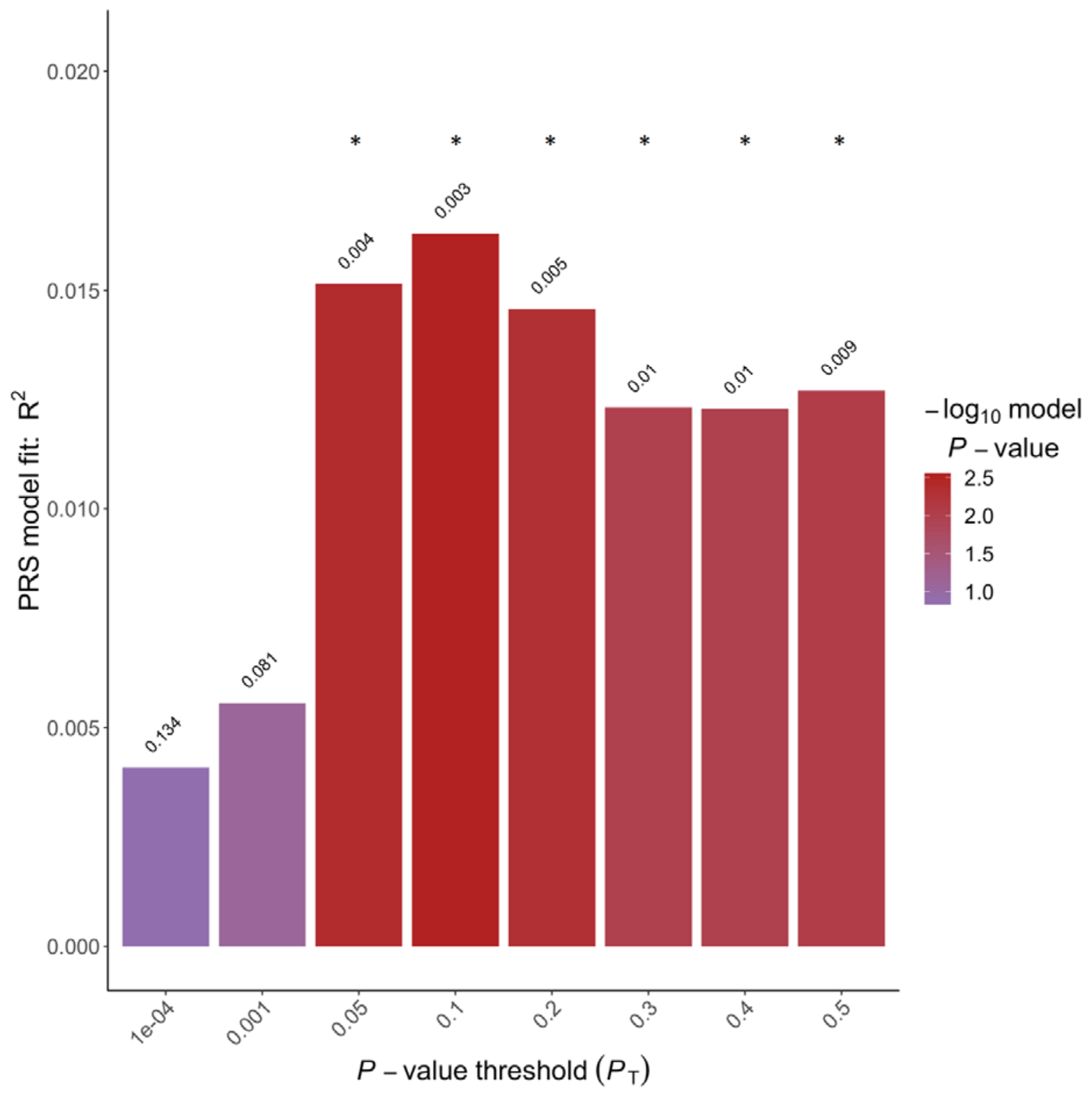


medRxiv preprint doi: https://doi.org/10.1101/2020.01.15.20017699; this version posted January 18, 2020. The copyright holder for this preprint

(which was not certified by peer review) is the author/funder, who has granted medRxiv a license to display the preprint in perpetuity.

All rights reserved. No reuse allowed without permission.

Figure 1b. Strata plot showing the quintiles of SCZ-PRSs plotted against their effect on nonresponse to antidepressants. The lowest SCZ-PRS quintile was used as reference $(\mathrm{OR}=1)$. $\mathrm{SCZ}=$ schizophrenia; PRSs=polygenic risk scores; GWAS=genome-wide association study.

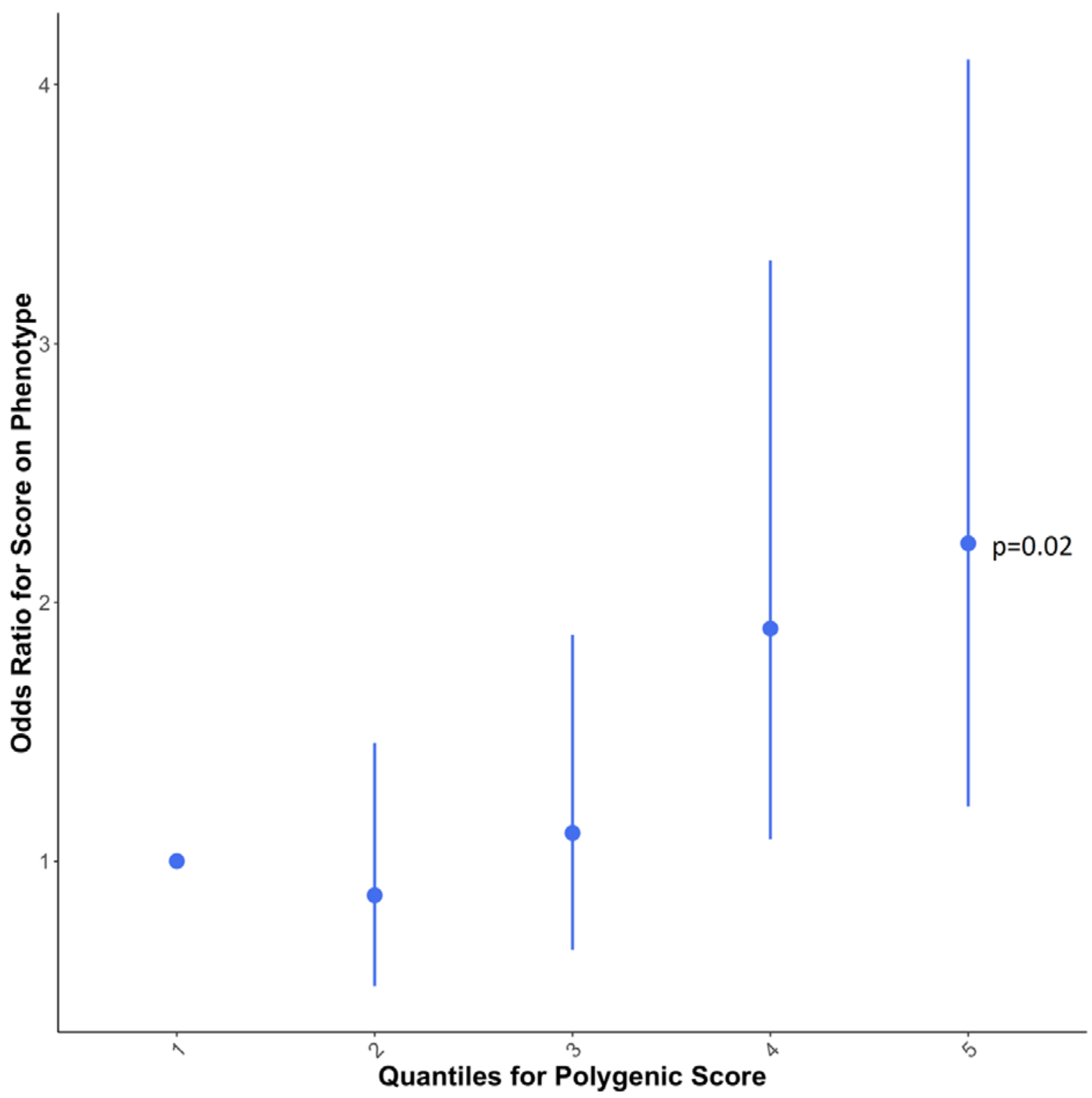


medRxiv preprint doi: https://doi.org/10.1101/2020.01.15.20017699; this version posted January 18, 2020. The copyright holder for this preprint (which was not certified by peer review) is the author/funder, who has granted medRxiv a license to display the preprint in perpetuity.

All rights reserved. No reuse allowed without permission.

Figure 2. Bar plot showing the response rate of patients with MDD who receive (in blue) or not receive (in red) augmentation with antipsychotics in low SCZ-PRS and high SCZ-PRS quintile $(\chi 2=7.89, \mathrm{p}=0.008)$. MDD, major depressive disorder; antipsychotics, antipsychotics, SCZ, schizophrenia; PRS, Polygenic Risk Score.

0.6

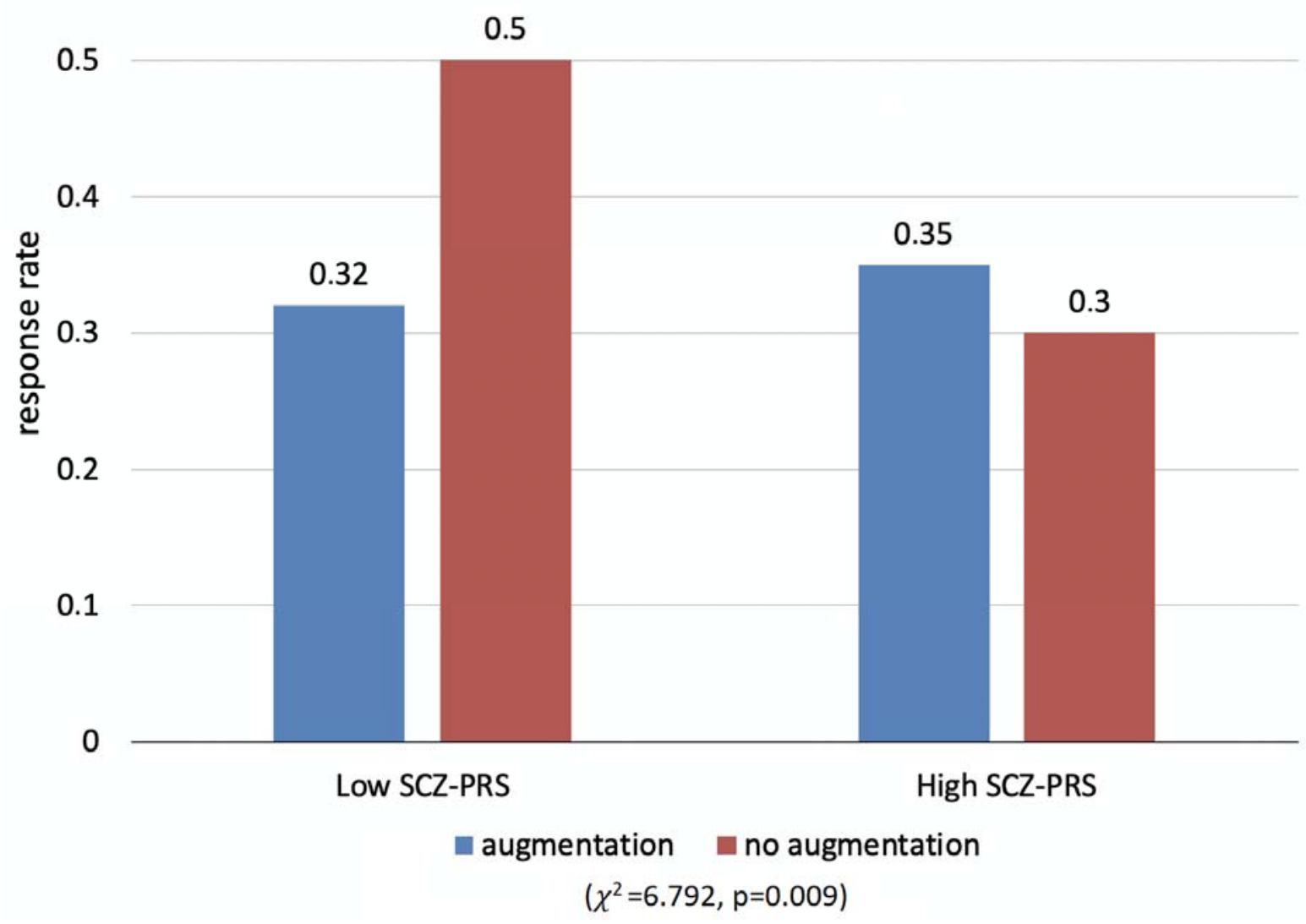

